\title{
Survey on the Production of Traditional Bioenergy in the Democratic Republic of the Congo: The Case Study of Kwilu Province
}

\author{
Masens Da-Musa Y.B. ${ }^{1 *}$, Koto-te-Nyiwa Ngbolua ${ }^{2}$, Briki C. Kakesa ${ }^{3}$, Muhammad \\ $\underline{\text { Ridwan }^{4}}$ \\ 1,2Department of Biology, Faculty of Science, University of Kinshasa, Kinshasa, Democratic Republic \\ of the Congo \\ ${ }^{2}$ Department of Environment, Faculty of Science, University of Gbado-Lite, Gbado-Lite, Democratic \\ Republic of the Congo \\ ${ }^{3}$ University of Kikwit, Kikwit, Democratic Republic of the Congo \\ ${ }^{4}$ Universitas Islam Negeri Sumatera Utara, Indonesia
}

\begin{abstract}
:
The present research has been carried out in three different groupings, namely Mudikwiti, Tanganga and Nkata in Kwilu province, in the Democratic Republic of the Congo. 165 coalmen from eighteen villages have been considered as the sample used in this work. They are selected from all social strata, and their ages vary from 18 to 30 years old and from 44 to 56 years old. They have made 21,899 ovens, among which there were 12, 287 ovens of small dimensions, that is, $1 \mathrm{~m} \times 6 \mathrm{~m} \times 3 \mathrm{~m}$, and 9,612 ovens of big dimensions: $6 \mathrm{~m} \times 20 \mathrm{~m} \times 3 \mathrm{~m}$. They have cut 196,694 trees of different species to fill in the two kinds of ovens, say 99,984 trees for filling in small ovens and 96,710 trees to fill in big ovens. On the whole, they have produced 852,708 sacks of charcoal per year. The Nkata grouping, with its 11 villages, has produced 129,600 sacks of 45 kilograms, divided as follows: 14,400 sacks from the small dimension ovens and 115, 200 sacks from the big dimension ovens.
\end{abstract}

\section{Keywords:}

ember fuel; deforestation; Mudikwiti; Tanganga; Nkata; ovens; sustainable development

\section{Introduction}

Traditional bioenergy dates back to time immemorial. It is still among the matters of topical interest. More than 90\% housework in in the Democratic Republic of the Congo (DRC) in general and in Kikwit and its surroundings in particular depends on it (Kambale et al., 2016; Ngbolua et al., 2018). In fact, as reported by Kpula et al. (2021), half of tropical forests in the planet have disappeared during the fifty last years and have been replaced by agricultural zones, fallow lands or urban developments, or used as the source of the charcoal energy and gas, etc. Its thoughtless use to excess by people does not occur in DRC only, but also in many developing countries, notably those of Africa in the south of Sahara, bringing thus numerous consequences such as accelerated disappearance of forest and savannah ecosystems (shrubbery, wooded and planted with trees, etc.). Recent findings revealed that the destruction of tropical forests constitutes the main source of charcoal and is evaluated annually at 1.6 billion of tonnes of supplementary coal poured in the atmosphere (Kambale et al., 2016; Otomba et al., 2017; Ngbolua et al., 2018).

Forest is also a source of bioenergy (biomass) for clay brick ma nufacturing. Clay brick is one of the most important materials for the construction in rural areas of Africa. However, the consumption of such earth-based materials in the production process resulted in resource depletion, environmental degradation, and energy consumption (Ngbolua et al., 2019). 
Our concern joins the one contained in the Congolese Forestry Code (2002), in its articles 2 and 4, title I. The combustion of this biomass coming from that of the charcoal constitutes, in fact, one of the major causes of the emission of greenhouse gas, notably of $\mathrm{C02}$, leading thus to the sensible increase of the atmosphere temperature, which is manifested by a climatic change characterizing our planet nowadays.

In the face of the quite daily deforestation undergone by forest and savannah formations observed in Kikwit and its hinterland, mostly on the main supply route between the sectors of Imbongo (Nkata Grouping), of Kwenge (Tanganga Grouping), and of Mosango (Mudikwiti Grouping) and whose consequences are very harmful for villages of those different entities in terms of wood for building houses, for housework, and the like, we have proposed to quantify, in terms of sacks of charcoal produced yearly, the impact of this activity on the existing vegetal formations, to list active coalmen (their ages, sex, social status, professional status, etc.) in those administrative entities.

Although demographic parameters used in this paper have not been analysed for their impact in the exploitation of charcoal in the concerned entities, it has to be noted that precarious conditions in which those social strata live compel them to turn resolutely to their forest clumps to solve somewhat their survival problems. Those poor social conditions influencing the life of Congolese people and leading to the deforestation of forest ecosystems provoke inescapably the loss of biodiversity. They have a harmful effect on the eco- climatic change and on the environment conservation as well.

\section{Research Methods}

To collect the data, a sample of 165 persons interviewed. Respondents were questioned individually based on a survey questionnaire in different villages of the three selected groupings under study in order to meet coalmen working in their ovens. The main data collected during the survey are related to sex, marital status, and age, education level and profession, kinds of ovens, number of the sacks of charcoal produced, kinds and number of used trees.

Forest clumps concerned in this work refer to paleo-climatic formations of the quaternary such as gallery forests and wooded savannahs or shrubs. In fact, apart from the two cultivated species that they use, other species are met in the environmental milieu and characterize herbaceous formations arborescent in the borders of the regional sub-centre of the Guinean-congolo-zambezian endemism (White, 1979). The sample of this work has been determined on the basis of the sacks of the charcoal produced by coalmen. Given the higher number of those charcoal producers, the number of 20 sacks per coalman or/and per group of coalmen were fixed.

The same criterion has been used to determine the number of villages and of groupings in each of the three above mentioned sectors. A total sample of 165 coalmen from Mudikwiti Grouping (Mosango Sector), Tanganga Grouping (Kwenge Sector), and Nkata Grouping (Imbongo Sector), giving a total of 18 villages divided as follows: 8 villages from Mudikwiti, 3 villages from Tanganga, and 7 villages from Nkata. 


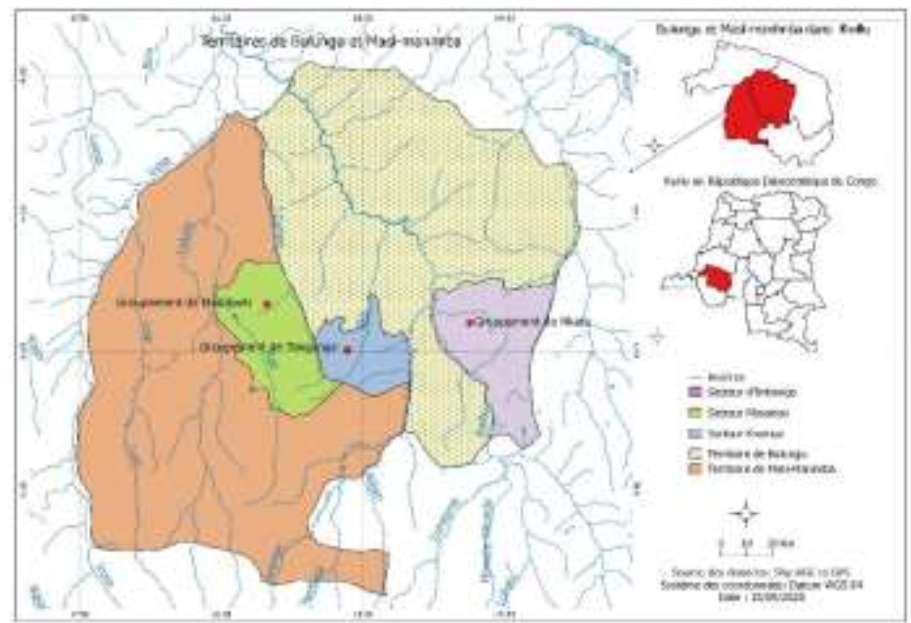

Figure 1. Localization of the Sites of Study in the Concerned Groupings

The plant species were determined in situ and then compared to the voucher specimen stored at the herbarium of the University of Kinshasa and of INERA (Institut national d'études et de recherches agronomiques). The classification of botanical materials has been highly made while revising the current taxonomy of APG III (2009) and IV (2016). The environmental and phyto-geographical spectra were determined according to the classification of Raunkiaer (1934) as quoted by Lubini (2001), Masens (1997), Nshimba (2008), and Habari (2009).

\section{Discussions}

\subsection{Species Exploited for the Making of Traditional Bioenergy}

Nineteen different plant species are exploited in the three groupings mentioned above. They belong to ten different families. Species of the Fabaceae family, mostly those of the subfamilies of Caesalpniodeae and Mimosoideae, are the most preferred by the coalmen of the three groupings. Among those species, (a) four species belong to savannah formations. They are Erythrophleumafricanum (Welw. ex Benth.) Harms, DialiumenglerianumHenriq., HymenocardiaacidaTul., and Maprounea AfricanaMül.; (b) two are farmed trees: Mangiferaindica L. and Persea Africana Mill., (c) one species of hydromorphic soil: Halleastipulosa (DC.) Leroy. Among the exploited species, four are noble species: Brachystegialaurentii (De Wild.) Louis, Miliciaexcelsa (Welw.)C.C. Berg., Millettialaurentii De Wild., and Prioriabalsamifera (Harms) Breteler. These species are, according to the information that we received from the coalmen, exploited because of their high heat capacity.

\subsection{Socio-Demographic Data of Coalmen}

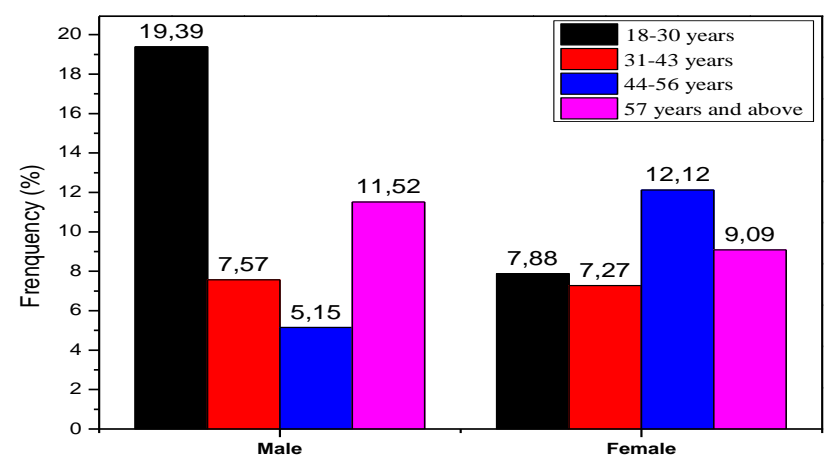

Figure 2. Distribution of Coalmen per Age 
The above figure reveals that the ages of the 165 coalmen vary from 18 to $\geq 57$ years old. For male, the age between 18-30 years old is most represented while the age between 44 56 years old is the most represented in female group.

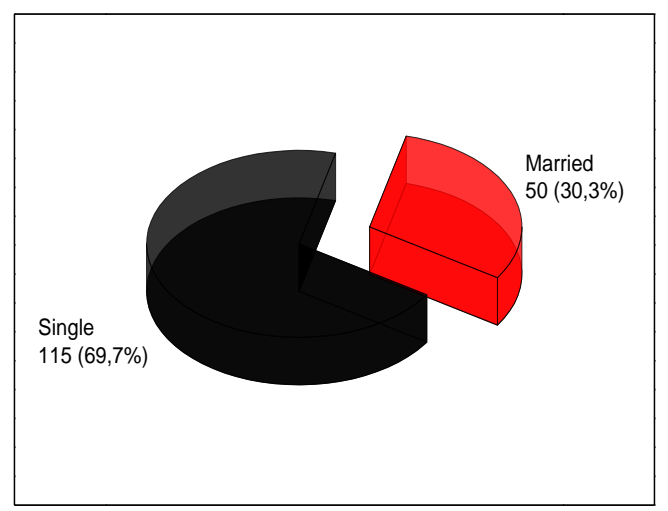

Figure 3. Distribution of Coalmen According to Marital Status

The figure 3 revealed that out of the 165 coalmen, there are 115 singles, representing $69.7 \%$, and 50 married $(30.3 \%)$.

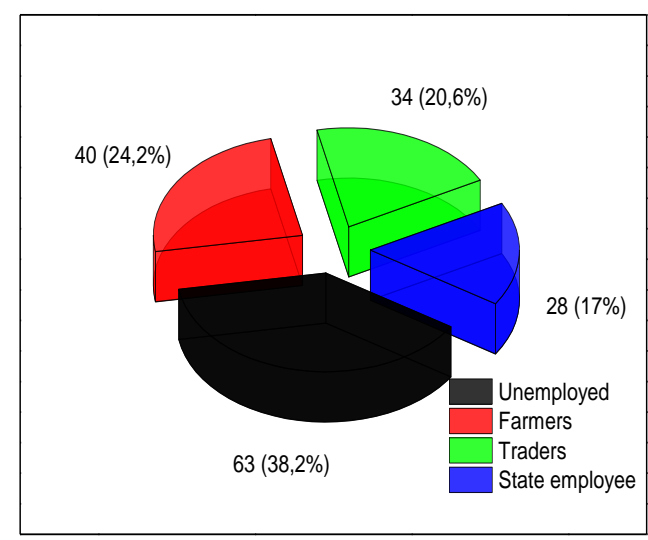

Figure 4. Distribution of Coalmen According to Their Professions

According to their professions, the 165 coalmen are divided into four groups: 34 traders (20.61\%), 28 state employee (16.97\%), 40 farmers $(24.24 \%)$ and 63 unemployed persons $(38.18 \%)$.

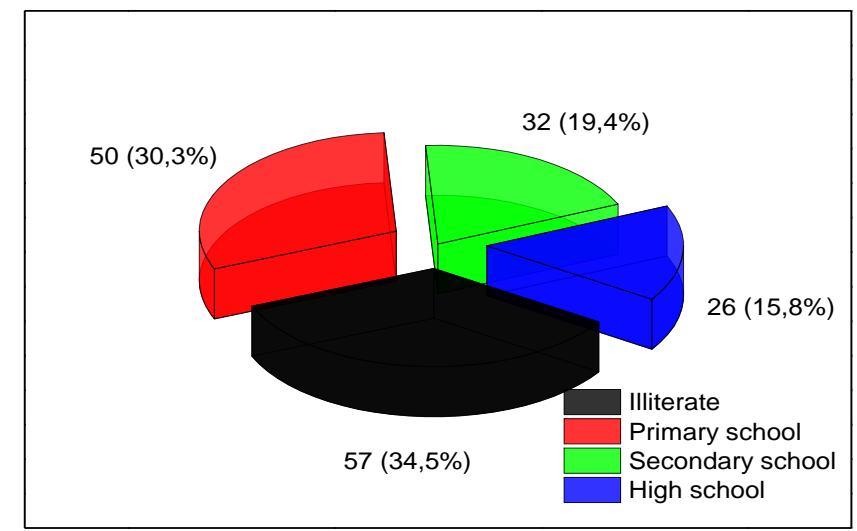

Figure 5. Distribution of Coalmen According to Their Study Levels 
Following the study levels of the 165 coalmen, there are four groups: 50 coalmen have attended the primary school (30.30\%); 32 coalmen have been in the secondary school (19. $39 \%) ; 57$ coalmen have no study level as they did not study (34.54\%) and 26 coalmen have studied at University or at College $(15.76 \%)$.

\subsection{Annual Production of Charcoal By the Coalmen of the Three Groupings}

All the ovens made yearly by the 165 coalmen are 21,899 divided as follows: 12,287 ovens of small dimensions and 9, 612 ovens of big dimensions. Those coalmen destroy a total of 196, 694 trees per year. The coalmen of Nkata Grouping, with its 11 villages, destroy yearly 63,840 trees $(63.85 \%)$ and 69,000 tress $(71.35 \%)$ to fill in respectively 6,960 ovens and 7, 080 ovens. Then, Mudikwiti Grouping follows in cutting respectively 28, 800 and 19, 200 trees yearly to fill in 2, 880 and 1, 920 ovens. Coalmen of Tanganga Grouping destroy 7, 344 and 8, 510 trees to fill in 2, 447 and 612 ovens. It follows that the 165 coalmen produce yearly 852 , 708 sacks of charcoal. Nkata Grouping produces the greatest number of sacks, that is, 671, 760 sacks, representing $78,78 \%$, excelling thus in the destruction of forest ecosystems. Mudikwiti Grouping comes in the second position with 129, 600 sacks of traditional bioenergy, representing $15.19 \%$. Coalmen of Tanganga Grouping seem to be less enterprising as they produce 51,348 sacks only, that is, $6.02 \%$. This work, based on the production of traditional bioenergy in the surrounding forests of Kikwit and its hinterland, has counted 19 forest species which are the most exploited by the 165 coalmen in the groupings of Nkata, Tangana and Mudikwiti. All those species are angiosperms whose 50\% are Fabaceae (Caesalpinioideae and Mimosoideae). Among the most used trees that may disappear soon if we do not care, there are these four kinds: Brachystegia laurentii, Milicia excelsa, Millettia laurentii, and Prioria balsamifera. This preference over those species leads to their disappearance and/or their scarcity in the hinterland of Kikwit.

This situation is provoked by the thoughtless cutting down of trees for different reasons. So, coalmen being small farmers have to make long distances to find such species.

Coalmen whose ages vary from 18 to 30 years old and from 44 to 56 years old are the most enterprising and active. In fact, it is in these two groups of ages that skilful coalmen are found as they are physically strong. Those being over 57 years old are somehow weak and thus unable to do such chores. The coalmen of the three groupings are either men or women, married or unmarried, young or old persons, educated people or not, employed or unemployed persons. So, they are of different strata and, given the poor conditions they are living in, they have become coalmen just to gain some money in order to solve somewhat their daily problems. Our inquiry in the field has revealed that those coalmen destroy systematically forests or groves where they still exist in the hinterland of Kikwit. In fact, every year, they produce 852,708 sacks of charcoal. It has to be noted that when a tree is cut, it damages many other young trees around it. This has a negative impact on the forest formations which, indeed, are systematically destroyed because of the many fields and wood that people cut yearly for different reasons. This thoughtless cutting of trees leads to atmospheric disturbance. This is why, nowadays in the province of Kwilu, we observe an increase of temperature causing climatic change, which is now a world phenomenon. The introduction of the chain saws by certain coalmen has accelerated the deforestation of ecosystems. Masens (2015) and Masens et al. (2017) have already alluded to that situation when writing successively on forest shrubs of Kamaba and of Nzundu in sectors of Kipuka and Imbongo. Forest species having become rare or having disappeared in the areas under study, coalmen are now moving here and there in some savannahs or groves still existing in the hinterland of Kikwit. 
Those savannah ecosystems are cleared from their populations of Erythrophleum africanum, Dialium englerianium, Hymenocardia acida and Maprounea africana, etc. and, little by little; those savannahs transform themselves to grassy savannahs and/or, at present, to the planting of Chromolaena odorata (L.) R.M. King. The same fate is for damaged forest formations.

\section{Conclusions}

By and large, it has to be noted that the systematic thoughtless destruction of forest trees in the hinterland of Kikwit is a serious danger for the people of surrounding villages already confronted with various socio-economical and unprecedented problems. There is a great risk that, in a near future, those people be confronted with a lack of wood for building their houses and of energy for their housework. This would ineluctably lead them to death and/or to rural exodus with all its consequences at the regional and national levels. The unprecedented increase of unemployed people in all the social strata do contribute to the destruction of some forest trees still growing in those areas. In fact, the financial socioeconomic situation of the average Congolese being very disastrous, people resort to forests for their survival. Considering the number of charcoal sacks produced by coalmen yearly, it is obvious to observe the thoughtless destruction of trees. By the way, the combustion of thousands of tonnes of this traditional bioenergy pours in the atmosphere tonnes and tonnes of $\mathrm{CO} 2$ confined for a long time by those species after their incineration. As a result, there is the increase of temperature because of the greenhouse gas provoking the climatic change known nowadays on the planet in general and in our areas in particular. To avoid an unprecedented ecological disaster looming up on the horizon, we suggest what follows:

- A pressing necessity to undertake reforestation works of ecosystems completely damaged or about to be damaged and of fallow lands.

- A necessity to undertake afforestation works of secondary and natural savannahs, grassy savannahs, open natural places, etc.

- An urgent necessity to respect the normal duration of fallow lands where it is not possible to make reforestation.

In addition, we advocate the policy of " 1 child for at least 2 shrubs" selected and planted by his parents. When the child is still a baby, his parents should take care of those shrubs until the baby will grow up.

The selected species should be chosen among natural ones, mostly those having a quick growth such as Senna, Trema guineensis (L.) Blume, Rauvolphia vomitoria Afzel, Myrianthus arboreus P. Beauv., Treculia africana Decne, Musanga cecropioides R. Br., etc. Those may be first planted for their shades and, later on, such other kinds may also be used: Brachystegia laurentii, Prioria balsamifera, Entandrophragma, Gilbertiodendron dewevrei (De Wild. J. Léonard, Milletttia laurentii, etc. To succeed all those suggestions, there must be welltrained community workers in social and cultural activities at all the levels of the Civil Service who should remind people what they have to do with reference to the topic debated in this paper. 


\section{References}

APG III (2009). Angiosperm Phylogeny Group. Botanical Journal of the Linnean Society 141: $399-436$.

APG IV (2016). Angiosperm Phylogeny Group. Tela Botanica (Botanical Journal of the Linnean Society). Vol. Earl View, p.1-20.

Code Forestier. Journal Officiel de la République démocratique du Congo. Loi no 011/2002 du 29 août 2002. Cedi: Kinshasa, p.38.

Habari M (2009). Etude floristique, phytogéographique et phytosociologique de la végétation de Kinshasa en République Démocratique du Congo. Thèse de doctorat, Faculté des Sciences: Université de Kinshasa.

Kambale JLK, Feza MF, Tsongo MJ, Asimonyio AJ, Salomo M, Nshimba H, Gbolo ZB, Mpiana PT, Ngbolua KN (2016). La filière bois-énergie et dégradation des écosystèmes forestiers en milieu périurbain: Enjeux et incidence sur les riverains de l'ile Mbiye à Kisangani (République Démocratique du Congo). International Journal of Innovation and Scientific Research 21(1): 51-60.

Kpula NM, Ngbolua KN, Assi RL, Nzamonga AG, Andia PL, Masengo CA (2021). Pratique de l'agriculture traditionnelle sur brûlis dans la commune de Molegbe (Gbado-Lite, Nord-Ubangi) en République Démocratique du Congo. Revue Marocaine des Sciences Agronomiques et Vétérinaires 9(4): in press.

Lubini AC (2001). Analyse phytogéographique de la flore forestière du secteur Kasaï au Congo Kinshasa. In Comptes rendus de la XVIème réunion plénière de l'AETFAT. Vol. 72, nº 2, Bull. Jard. Bot. Nat. Belg., Bruxelles, p.382.

Masens d-MYB (1997). Etude phytosociologique de la région de Kikwit (Bandundu, Zaïre). Thèse de doctorat, Faculté des Sciences (Laboratoire de Botanique Systématique et Phytosociologie., Université Libre de Bruxelles : Belgique, p.382.

Masens d-MYB (2015). Contribution à l'étude phytoécologique de la forêt de Kamaba (Kipuka, district du Kwilu, province de Bandundu, R.D. Congo). Congo Sciences (Journal en ligne de l'ACASTI et CEDESURK) 3:31-32.

Masens d-MYB, Ngbolua KN, Masens M, Tembeni MT, Bongo N (2017). Phytosociological study of Nzundu massif forest of Imbongo city, Kwilu province, Democratic Republic of Congo.Tropical Plant Research 4(3): 363-375.

Ngbolua KN, Ndanga A, Gbatea A, Djolu R, Ndaba M, Masengo C, Likolo J, Falanga C, Yangba S, Gbolo B, Mpiana P, 2018. Environmental Impact of Wood-Energy Consumption by Households in Democratic Republic of the Congo: A Case Study of Gbadolite City, Nord-Ubangi. International Journal of Energy and Sustainable Development 3(4): 64-71.

Ngbolua KN, Falanga MC, Djolu DR, Masengo AC, Nzamonga GA, Bongo NG, Gbolo ZB, Mudogo V, Mpiana PT (2019). Socio-economic and Environmental Impacts of Clay Brick Manufacturing in Gbado-Lite City (Nord Ubangi Province, DR Congo). Journal of Environment Protection and Sustainable Development 5(3): 126-131.

Nshimba SM (2008). Etude floristique, écologique et phytosociologique des forêts de l'île Mbiye à Kisangani, RDC. Thèse de doctorat, Université Libre de Bruxelles: Belgique.

Otomba IC, Bwama MM, Muanasaka KL, Verbist B, Moonen P, Asimonyio JA, Ngbolua KN (2017). Identification des moteurs de déforestation et incidence socioenvironnementale dans une économie du marché à l'hinterland de la ville de Kisangani (Province de la Tshopo) en République Démocratique du Congo: Effets \& stratégies. International Journal of Innovation and Scientific Research 33 (2): 186-197.

Raunkiaer C (1934). The life forms of plants and statistical plant geography. Oxford: Clarendon Press, p.632.

White F (1979). The Guineo-Congolian Region and Its Relationships to Other Phytochoria. Bulletin du Jardin Botanique National de Belgique 49: 11-55. 